Professor Kolst $\varnothing$ har arbeidet som lektor i skoleverket og arbeider nå med lærerutdanning ved Universitetet

i Bergen. Hans forskningsinteresser knytter seg til betingelser for at naturfagundervisning skal fungere

allmenndannende. Spesielt forsker han på hvordan praktisk arbeid i naturfag kan bidra til $\emptyset$ kt forståelse for

naturvitenskapenes egenart og fremme elevenes evne til å lese, samtale og skrive om naturfaglige emner.

STEIN DANKERT KOLST $\varnothing$

Institutt for fysikk og teknologi, Universitetet $i$

Bergen, Norge

kolsto@ift.uib.no

\title{
Vektlegging av lesing i naturfaget. Del 1: Vil den nye norske læreplanen i naturfag $\varnothing$ ke elevenes lesekompetanse?
}

\begin{abstract}
In the Norwegian curriculum reform, coined "Kunnskapsløftet," reading is introduced as one of five basic skills to be emphasised in all subjects, including science. Due to the presence of science-related information and debate in society, competence in reading scientific texts should be considered an important aspect of scientific literacy. In this article I review literature which indicates that many students find it hard to read scientific texts, many science teachers are not aware of the importance of teaching students to read in science, and reading instruction is not common in school science. I the refore present an examination of the emphasis on reading in the new Norwegian science curriculum. Based on the analysis I conclude that, contrary to the intension in the curriculum reform, reading has not received the necessary emphasis to change this picture.
\end{abstract}

\section{HVORFOR ER LESING I NATURFAG VIKTIG?}

Kritisk lesing og vurdering av naturfaglig informasjon er tema i læreplaner i naturfagene $\mathrm{i}$ alle nordiske land. I den nye norske læreplanreformen 'Kunnskapsløftet" er å kunne lese, skrive, uttrykke seg muntlig og bruke digitale hjelpemidler vektlagt som grunnleggende ferdigheter som skal vektlegges i alle fagplaner. Lesing som tema i naturfag har derfor fått en aktualisering i Norge som gjør det nødvendig å diskutere hvilken status leseopplæring har i naturfaget.

I Stortingsmelding nr. 30, Kultur for laering (Utdannings og forskningsdepartementet, 2004), som lå bak læreplanreformen i Norge i 2006, påpekes det at "Det å kunne lese er en ferdighet som er nødvendig for å delta i samfunnet som en kritisk og reflektert borger og en forutsetning for personlig utvikling (s.32). Representanter for den australske sjangerskolen peker på at det å kunne lese og skrive i ulike sjangre innebærer mulighet for å kunne delta i flere arenaer forbundet med makt i samfunnet. Kjennskap til naturfagets sjangre er derfor viktig for at flere skal få tilgang til faglige tekster og situasjoner hvor slike brukes (Halliday \& Martin, 1993; Keys, Hand, Prain \& Collins, 1999). Tekster med naturfaglig innhold møter vi alle i aviser, magasiner, internett, i brosjyrer fra legen og andre, og ofte også i jobbsammenheng i forbindelse med temaene helse, miljø og sikkerhet (HMS). Disse tekstene kan være rapporter med nye forskningsresultater, argumenterende innlegg i debatter med en naturvitenskapelig dimensjon (sosiovitenskapelige debatter), miljøutredninger, anvisninger for bruk av medisiner og kjemikalier, informasjon om HMS og energiøkonomisering 
og forklaringer av naturvitenskapelige begrep (for eksempel faktabokser i avisen og helseinformasjon på internett).

Eksemplene illustrerer det faktum at naturvitenskapelig informasjon og argumentasjon inngår i en rekke situasjoner i dagens samfunn. Når naturvitenskapelige forskningsresultater brukes i debatter knyttet til politiske spørsmål blir den enkeltes mulighet for demokratisk deltagelse betinget av mulighetene for å kunne lese tekster med naturfaglig innhold. Det som kalles sosiovitenskapelige kontroverser er nettopp definert som diskusjoner i det offentlige rom som har en naturvitenskapelig dimensjon (Kolstø, 2006). Aktuelle eksempler er diskusjoner knyttet til jordens klima, energiproduksjon, nanoteknologi, bioteknologi, genmodifiserte jordbruksprodukter, tilsetningsstoffer i matvarer, mobilstråling, luftforurensning og fiskeoppdrett.

Ofte er forståelse av naturvitenskapelige begrep nødvendig for å forstå problemstillinger i slike debatter og skille ulike spørsmål fra hverandre. I en studie fant Lewis og Leach (2006) at elever som forsto for eksempel forskjellen mellom kjønnsceller og andre celler dårlig, tenderte til å blande ulike diskusjoner knyttet til anvendelser av bioteknologi. I mange saker inngår det naturvitenskapelige forskningsstudier og offentlige utredninger av helse eller miljøaspekt. I tillegg vil ulike aktører produsere innspill hvor det typisk inngå naturfaglige argumenter. Det vil si argumenter hvor naturvitenskapelige forskningsresultater brukes som begrunnelser.

Naturvitenskapelige begreper og argumenter inngår også i mange diskusjoner knyttet til valg vi må gjøre som forbrukere. Bør jeg for eksempel kjøpe økologiske matvarer, elektrisk bil, mat tilsatt vitaminer eller hagemøbler laget av teak? I det siste eksempelet inngår det blant annet diskusjoner om konsekvenser for biodiversitet og jordens klima. Borgere som strever med å lese tekster med naturfaglig innhold vil ha mindre mulighet til skaffe seg kunnskap og å delta diskusjoner i slike saker. Maagerø og Tønnesen (2006) påpeker at ulike fagtradisjoner byr på ulike leseutfordringer for elevene, og at "lesing derfor må trenes og videreutvikles i alle fag" (s.24). Leseopplæring i naturfag blir derfor nødvendig hvis vi ønsker å for å fremme økt demokratisk deltagelse i sosiovitenskapelige kontroverser.

Innen naturfagdidaktikken har lesekompetanse i naturfag fått økt oppmerksomhet gjennom Norris og Phillips (2003) sitt begrep om fundamental scientific literacy. Begrepet tar utgangspunkt i en påstand om at utvikling av naturvitenskaplig kunnskap er uløselig forbundet med utvikling av språk som uttrykker denne kunnskapen (Wellington \& Osborne, 2001). Naturfagets begreper og teorier er laget for å utvikle vår forståelse av fenomener og årsakssammenhenger i naturen. Denne forståelsen er ikke direkte observerbar men skal forklare det observerbare. Derfor, i den grad naturfag går utover det rent beskrivende, er naturfaglig kunnskap abstrakt kunnskap som bare kan utvikles og formidles gjennom språk og symboler (Norris \& Phillips, 2003). Skriving og lesing er grunnleggende viktig for kunnskapsutvikling og læring også fordi det muliggjør lagring av kunnskap samt interaktiv, reflektert og kritisk lesing og vurdering. Dette gjør naturfag krevende å lære og å lese, men det synliggjør samtidig at naturfaglig allmenndannelse (scientific literacy), i Norris og Phillips fundamentale betydning, må inkludere skriving og lesing i naturfag.

Mitt inntrykk er at mange antar at hvis bare elevene lærer de nødvendige naturvitenskapelige begrep, så vil lesing av naturfaglige tekster utenfor skolen gå greit. Denne antagelsen er i utakt med resultater fra leseforskning (Dole, Duffy, Roehler, \& Pearson, 1991; Maagerø \& Tønnesen, 2006; Norris \& Phillips, 2003). Antagelsen innebærer også en påstand om at overføring av kunnskap fra en situasjon - lese lærebøker og skrive begrepsforklaringer på skolen, til nye kontekster - lese autentiske tekster utenfor skolen, er uproblematisk. Slik overføring vet vi fra forskning (Anderson, Simon, \& Reder, 1996; Layton, 1991) at er krevende. Som lærere og lærerutdannere har mange av oss fått bekreftet at elever ofte kommer til kort når vi ber dem anvende kunnskap i nye typer av situasjoner. Læring av naturvitenskapelig begreper og sammenhenger må derfor suppleres med opplæring i lesing av naturfaglige tekster. 
Tilfanget av naturfaglige begreper i tekster elevene vil møte gjennom livet aldri vil kunne få plass innenfor rammen av en læreplan. Samtidig ønsker vi, i et demokratisk perspektiv, at alle skal kunne lese tekster som er aktuelle for egen livssituasjon. Da er det ikke nok at elevene blir i stand til å lese tekster med kjente naturfagord. Elevene må også bli i stand til å bruke lesing til å lære betydningen av for dem nye begreper. Dette innebærer at vi i naturfag bør vektlegge lesekompetanse som grunnlag for livslang læring av naturfag. Dette poenget forsterkes av at lesing også er nødvendig for læring av naturfag underveis i utdanningsløpet. Det er her interessant å merke seg at utredningene som lå bak den nye norske læreplanreformen, I første rekke (Utdannings- og forskningsdepartementet (2003) og den nevnte Stortingsmeldingen Kultur for laering (Utdannings og forskningsdepartementet, 2004) vektla lesing som spesielt betydningsfullt for livslang læring. Også i PISA sine rammeverk for leseundersøkelsene (Kjærnsli, Lie, Olsen, \& Roe, 2007; Lie, Kjærnsli, Roe \& Turmo, 2001) påpekes viktigheten av lesing for livslang læring.

Hvis lesing er viktig for demokratisk deltagelse og livslang læring blir det viktig å undersøke hva vi vet om elevers dyktighet til å lese slike tekster. Det er også av betydning å undersøke vektleggingen av leseopplæring i naturfaget, samt hvilken vekt lesing er gitt $\mathrm{i}$ den nye norske læreplanen i naturfag. Formålet med denne artikkelen å undersøke disse temaene nærmere. Denne artikkelen er den første i en serie på to hvor jeg undersøker spørsmålet om hvilke utslag lesingens sentrale posisjon i forhold til opplæringens mål har fått for naturfagets rammer og innhold. På bakgrunn av resultatene i denne artikkelen vil jeg i den andre artikkelen diskutere hva som kan gjøres for å fremme elevenes kompetanse til å lese naturfaglige tekster med forståelse (Kolstø, 2009).

\section{HVA VET VI OM ELEVENES LESEKOMPETANSE?}

Innen leseforskning er det i dag enighet om at det å lese er en interaktiv prosess der leseren prøver å forstå det som leses i lys av egne kunnskaper, erfaringer og forventninger til teksten, samtidig som ord tolkes i lys av sammenhengen de står i, tekstdeler tolkes i lys av tekstens helhet, og tekstens mening søkes forstått i lys av sammenhengen den inngår i (Dole m.fl. 1991; Maagerø \& Tønnesen, 2006; Norris \& Phillips, 2003). Dette innebærer at lesing er en prosess der leseren prøver å skape mening og forståelse og derigjennom utvikler sin egen oppfatning eller tolkning av teksten. En slik interaktiv oppfatning av lesing med forståelse harmonerer med konstruktivistiske læringssyn der læring forstås som et samspill mellom forhåndsforståelser og ytre stimuli.

Det å kunne skape mening i en tekst innebærer derfor mer enn å kunne lese alle enkeltord som inngår i teksten, såkalt avkoding, selv om det også er viktig. Innen leseforskning er det derfor vanlig å dele begrepet lesing inn i et teknisk aspekt - avkoding, og et meningsaspekt - forståelse (Dole m.fl. 1991; Gregg \& Sekers, 2006; Maagerø \& Tønnesen, 2006; Norris \& Phillips, 2003). Lesingens tekniske aspekt læres i den første fase av leseopplæringen. Gitt en interaktiv forståelse av lesing vil ikke det å kunne avkode automatisk innebærer kompetanse i å kunne lese med forståelse. Forståelsen av en tekst derfor kan mangle selv om den bare inneholder kjente ord.

Når elevene kommer til naturfagundervisningen vil de normalt kunne lese i betydningen avkode. Gjennom naturfaget lærer de etter hvert betydningen til flere og flere naturfaglige begreper. Når lesing med forståelse forutsetter mer enn avkoding og faglig begrepsforståelse, blir det likevel nødvendig at naturfaglærere ikke tar for gitt, uansett trinn, at elevene allerede kan lese fagtekster når de kommer til naturfagundervisningen. Målet bør da være at naturfaget gir en leseopplæring som bygger på kunnskap om hva som kan tenkes å hemme elevenes kompetanse i å lese naturfaglige tekster med forståelse. I en oversiktsartikkel om undervisning i lesestrategier peker Bryant, Ugel, Thomson og Hamff (1999) på at svake lesere typisk viser manglende interesse for lesing og emner de forventes å lese om, de begynner lesingen uten å se for seg et formål med lesingen, og de tenker ikke igjennom hva de har av relevant forhåndskunnskap. Underveis når de leser har de problemer 
med å dekode ord med mange stavelser, de mangler strategier for å finne ut betydningen av nye og ukjente ord og for å reparere forståelsesproblemer, og de leser videre selv om de ikke forstår det de leser. I etterkant av lesingen greier de ikke oppsummere innholdet og reflekterer heller ikke over det de har lest. Det er også et typisk trekk at svake lesere ofte ikke er klar over at de ikke har forstått det de har lest, og at de har en tendens til å tro at forståelse handler om å stave ordene riktig (Maagerø \& Tønnesen, 2006).

I en studie av to norske åttendeklasser (Mortensen-Buan, 2006) tydet observasjoner og elevsvar på at når elevene leste i lærebøkene var det få elever som leste nøkkelord eller reflekterte over innhold i forkant av lesing, bladde igjennom for å få en oversikt over det som skulle leses, så på bildene eller stilte spørsmål om formål med lesingen. Samtidig leste de fleste fort for å bli ferdige med lesingen. Flere forskere har påpekt at mange elever ikke egentlig leser tekster lærerne gir dem som leseaktivitet. De leser kontrollspørsmålene først og leter så i teksten for å finne svaret (Edling, 2006; Helgevold \& Engen, 2006; Knain, 2002; Mortensen-Buan, 2006; Quiocho, 1997). Edling (2006) refererer her følgende uttalelse fra en svensk elev på 8. trinn:

nä han sa bara läs igenom den ett par sidor först ja titta på ja gjorde ja titta på frågerna sen läste ja igenom efter sen tog ja fråga två sen läste igenom såhär fråga två 'vad är ett eldhus' här står det ju eldhus (visar i boken).

Hun kommenterer at leseaktiviteten her fikk elevene til å fokusere på detaljer i teksten i stedet for helhetlig forståelse. Helgevold og Engen (2006) hevder at mange elever mangler kunnskap om lesing av fagtekster, tro på egne evner til å kunne lese og lære fra fagtekster, og at mange ikke ser på lesing som et viktig redskap i egen læring.

I en studie hvor elever på en amerikansk high school ble bedt om å lese nyhetsnotiser om naturfaglige forskningsfunn fant Phillips og Norris (1999) at de fleste elevene ikke greide å begrunne sine tolkninger ved å henvise til informasjon i tekstene. De maktet heller ikke å integrere egen kunnskap med tekstenes innhold. I en liknende studie fant Ratcliffe (1999) at de fleste av 120 elever i ulike aldre (11-35 år) vurderte grad av sikkerhet riktig når teksten signaliserte at en påstand var sikker, men at flere tilla usikre påstander større sikkerhet enn teksten gav grunnlag for. I en annen slik studie fant Norris og Phillips (1994) at under halvparten av elever på 12. trinn mestret oppgaver som krevde kontekstualisert tolkning, og mange av elevene tilla påstander større grad av sikkerhet enn det forfatteren signaliserte. Mange elevers tolkning av påstandene i tekstene var således mangelfull.

Et signal om at norske elevene strever med å lese med forståelse er de svake resultatene for norske elever i PISA undersøkelsene. I PISA 2006 (Kjærnsli m.fl., 2007) hadde 22 av 30 OECD-land høyere gjennomsnittsskår i lesing enn Norge. Basert på visse prosedyrer for sammenlikning over tid fant de at norske elever skårte svakere i 2006 enn i 2003. Videre havnet 22\% av norske elever på de to laveste kompetansenivåene i lesing, nivå 0 og 1 på en skala fra $0-5$. Forfatterne av den norske PISA-rapporten for 2006 konkluderer med at "disse elevenes leseproblemer vil hindre dem i deres videre utdannelse, ja faktisk i å 'fungere tilfredsstillende i et moderne samfunn' " (Lie m.fl., 2001, s.112). At hver femte elev skårer så lavt er selvfølgelig urovekkende, selv om det kan være at en del av disse elevene ikke har lagt innsats i å svare ordentlig på oppgavene (Sjøberg, 2007).

Når det gjelder naturfag bruker PISA et oppgaveformat for naturfagoppgavene som innebærer krav til lesing av oversatte autentiske tekster (tekster som ikke er konstruert for test eller undervisningsformål). Norske elevers relativt svake skåre i naturfag kan derfor også leses som en indikasjon på at mange norske elever strever med å lese naturfaglige tekster. 


\section{HVA KAN GJ $\emptyset$ RE DET KREVENDE ^̊ LESE NATURFAGLIGE TEKSTER?}

Mer kunnskap om naturfaglige tekster kan her gi økt forståelse for hva som representerer utfordringer for elevene når de skal lese slike tekster. Et typisk trekk ved naturfaglige tekster er at de inneholder nominaliseringer (Halliday og Martin, 1993). Det innebærer at et verb eller et annet ikke-substantiv gjøres om til et substantiv, dvs et nomen. Med utgangspunkt i verbene stråle, reagere og kondensere har naturvitere laget substantivene stråling, reaksjon og kondensasjon. Slike nominaliseringer innebærer ofte at en setter navn på fenomen eller prosesser i naturen. Ved å bruke nominaliseringer kan den som skriver referere til en hel prosess ved hjelp at et enkelt ord, og så legge til mer informasjon om fenomenet innen rammen av en setning. I Brandt m.fl. (2006) sin lærebok i naturfag for 11. trinn finner vi for eksempel følgende setning: "Det blir frigitt mye mindre energi ved celleånding uten oksygen enn ved celleånding med oksygen" (s.105). Her brukes det sammensatte substantivet "celleånding" hvor ånding er en nominalisering av verbet ånde. Ved å bruke denne nominaliseringen har forfatteren kunnet gi ytterligere informasjon om celleånding innen en enkelt setning uten å måtte repetere forklaringen av prosessen. Martin (1993a) peker på at bruk av nominaliseringer er en av de viktigste forskjellene mellom dagligspråk og fagspråk. Videre ser vi at setningen er upersonlig (passiv stemme) ved at det ikke er mennesker som handler, men "det" eller "cellen" (eller celleåndingen?). Veel (1997) peker på at tid og rom ofte er fraværende i naturfaglige tekster og det brukes begreper som ikke representerer konkrete størrelser som kan sees eller berøres. Setningen over eksemplifiserer begge disse trekkene, det siste gjennom begrepene energi og celleånding. I naturfaglige tekster vil også mange begreper fra dagliglivet, som kraft, reaksjon og celle, tillegges en ny og presis faglig betydning, og faglige begreper vil ofte være klart definerte i forhold til hverandre og ordnet i hierarkiske strukturer (Martin 1993a; b). I tillegg vil antall faguttrykk i hver setning være høyt (Veel, 1997). Resultatet er at tekstene lett blir tunge og abstrakte å lese. I en studie av svenske lærebøker konkluderte Engel (2006) med at de 20 tekstutdragene fra naturfagbøkene hadde høyt abstraksjonsnivå, hyppig bruk av nominaliseringer og teknisk språk. Edling (2006) hevder videre at det å lære å lese og skrive tekster på nye og mer abstrakte måter i praksis er, og bør være, et sentralt mål for opplæringen i fagdisipliner. Hun trekker frem følgende setning fra en lærebok for barneskolen: "Tiden jorden bruker på å rotere rundt sin egen akse er et døgn" (s 58, min oversettelse). Hun peker så på at det som her er nytt for elevene ikke er selve innholdet, men måten kunnskapen er organisert og presentert på.

Et annet typisk trekk ved naturfaglige tekster er multimodalitet (Løvland, 2006). Multimodalitet innebærer at teksten ikke bare består av skrevet tekst, men av flere ulike modaliteter som bilder, tegninger, tabeller, formler, med mer, og i elektroniske medier kanskje også hypertekst, animasjoner og simuleringer. Ulike modaliteter kan ha ulik potensiale, gjerne kalt modal affordans, for å få frem et budskap. Fotografi, tabeller og annen grafikk får lett frem romlige og kvantitative forhold, mens skrevet tekst er godt egnet til å beskrive kvalitative sammenhenger og tidsrelasjoner (Lemke, 1998; Løvland, 2006). En forfatter kan derfor gjøre bruk av ulike modaliteter til ulike formål, med den hensikt å få et innhold tydelig frem. Dette innebærer at figurer og andre grafiske elementer bør leses i samspill med teksten. I stor grad må leseren her selv bestemme når øyne og mentalt fokus skal skifte mellom de ulike modaliteter i teksten. På tross av viktigheten av dette samspillet fant Mortensen-Buan (2006) i sin undersøkelse i to åttendeklasser at få av elevene så på bildene når de leste. I tillegg til veksling mellom ulike modaliteter i tekster kan lesing av grafer, diagram og tabeller være krevende for mange elever. Slike tekstelementer (kalt ikke-kontinuerlige tekster) inngår derfor i mange av leseoppgavene i PISA-undersøkelsene (Lie Kjærnsli, Roe \& Turmo, 2001).

Et tredje trekk ved naturfaglige tekster er at de inneholder påstander med det vi kan kalle ulik epistemisk status. Med epistemisk status menes her forfatterens signaler i teksten om en påstands grad av sikkerhet eller pålitelighet, eller grad av konsensus i et fagmiljø om en påstands pålitelighet. I en studie av relevansen av kunnskaper om naturvitenskap for lekfolk, fant Osborne, Collins, Ratcliffe, Millar og Duschl (2003) at ulike ekspert vurderte slik epistemisk kunnskap som svært viktig. I en lærebok eller en forklaring vil normalt alle påstander bli fremsatt som naturfaglige fakta. Men 
dette gjelder ikke for en eksperimentrapport. Her vil selve formålet med rapporten nettopp være å legge frem en hypotese. Hovedpåstanden i en eksperimentrapport kan derfor ha lav epistemisk status. Samtidig kan forfatteren i deler av rapporten legge frem påstander fra litteraturen med høy eller midlere epistemisk status. En slik kombinasjon av påstander med ulik epistemisk status kan vi også finne i utredninger og debattinnlegg. Skal elever kunne lese naturfaglige tekster med forståelse og kritisk distanse må de kunne gjenkjenne hvordan en forfatter tillegger ulike påstander ulik epistemisk status. Men det å vurdere påstanders epistemiske status er ikke nødvendigvis enkelt. Vi så ovenfor at forskningen på elevers lesing av nyhetsnotiser om forskning bekreftet dette. I tillegg til kunnskaper om naturvitenskaplig kunnskapsutvikling innebærer dette at de må kunne gjenkjenne antagelser som antagelser, hypoteser som hypoteser, fakta som fakta og konklusjoner som konklusjoner (Norris \& Phillips, 2003).

Et fjerde trekk er at naturfaglige tekster, på samme måte som tekster innen andre fagområder, skrives i ulike sjangre. Hvis en ikke kjenner formålet med en tekst, vil det være mer krevende å forstå hva som søkes formidlet. Typisk vil noen naturfaglige sjangre bli brukt når en referer etablert kunnskap, mens andre brukes når en vil argumentere for et synspunkt. En skriftlig forklaring kan en for eksempel vurdere om stemmer med etablert forståelse på et fagfelt, og argumentene $\mathrm{i}$ en utredning kan en vurdere om er relevante og holdbare. Tilsvarende må en laboratorieprosedyre leses på en annen måte enn en argumenterende tekst. Innen et sosialsemiotisk syn på språk betraktes sjangre som sosialt konstruerte språkpraksiser som reflekterer et fellesskaps normer og forventninger (Purcell-Gates, Duke \& Martineau, 2007). Ulike sjangre vil således ha ulike sosiale formål, være situert i sosiokulturelle kontekster, og undergå endring over tid. En kan således finne at naturfaglige sjangre vil fylle ulike funksjoner innen naturvitenskapene. Martin (1993b) har identifisert begrepsoversikt (report), forklaring (explanation), eksperimentprosedyrer (experiment - procedural), eksperimentrapport (experiment - recount), utredning (exposition) og biografi (biography) som sentrale naturfaglige sjangre. En begrepsoversikt har som mål å formidle fagområdets måte å kategorisere og beskrive naturen på innen et emne. Et eksempel her kan være en utlegning av naturvitenskapens inndeling av stoffer basert på ulik elektrisk ledningsevne i metaller, halvmetaller og ikke-metaller. (En naturfaglig beskrivelse slik vi ofte finner de på lavere klassetrinn kan kanskje sies å være en begrepsoversikt som begrenser seg til ytre observervare kjennetegn.) En naturfaglig forklaring søker å få leseren til å forstå årsakssammenhenger. En lærebok i naturfag vil typisk inneholde mest begrepsoversikter samt forklaringer og eksperimentprosedyrer (Martin 1993b). Prosedyretekster, enten det er eksperimentprosedyrer, sikkerhetsinstrukser, prosedyrer for laboratoriearbeid eller bruksanvisninger for teknisk utstyr, søker å få leseren til å utføre bestemte handlinger. En eksperimentrapport argumenterer for en hypotese og søker å overbevise leseren om verdien av denne gjennom å bruke empiri og annen evidens i underbyggende argumenter (Bazerman, 1988; Martin, 1993b; Latour, 1987; Veel, 1997). Martin legger her mest vekt på det å beskrive et eksperiment og mindre vekt på det å legge frem og overbevise om en påstands gyldighet. Dette ser ut til å skyldes at Martin fokuserer mer på den typiske skoleutgaven av sjangeren enn på den som brukes av profesjonelle naturvitere. I en utredning eller et debattinnlegg søker forfatteren å overbevise leseren om at et bestemt standpunkt i en sak er best begrunnet. Dette kan for eksempel være en offentlig miljøutredning hvor forfatteren forventes å vurdere ulike sider i en sak, for så å gi en faglig begrunnet konklusjon. En biografi har som mål å gi en fremstilling av livet og de vitenskapelige bidragene til en eller flere naturvitere. Hvis elevene ikke gjøres kjent med sentrale naturfaglige sjangre gjennom naturfaget vil mange kunne forbli ukjente med mange av disse.

Vi har indikasjoner fra forskning på elevers lesing som bekrefter at de ulike trekkene ved naturfaglige tekster referert ovenfor kan være utfordrende for elever. I en dybdestudie av to elevers lesing av en forenklet autentisk eksperimentrapport i biologi fant Brill, Falk og Yarden (2004) at forståelsesproblemer nettopp var knyttet til ukjente uttrykk, inkonsistens med egne forforståelser, forståelse av sammenheng mellom figur og tekst samt tekstens struktur. I studien av Norris og Phillips (1994) referert ovenfor så vi at mange elever strevde med å se hvordan ulike påstander var tillagt ulik epistemisk status. 
Ingen av trekkene som her er beskrevet er unike for naturfaglige tekster. Tvert imot er de typiske for alle fagtekster. Men samtidig blir de realisert på sin unike måte i naturfaget: Naturfaget har sine egne nominaliseringer, stor grad av mulitimodalitet, egne utfordringer knyttet til identifisering av epistemisk status og egne krav til kontekstkunnskap. Selv om ikke målet vil være at elever skal kunne lese alle typer naturfaglige tekster, så vil de typiske trekkene referert her finnes igjen i mediaoppslag og andre tekster som bygger på naturfaglige tekster.

\section{HVORDAN VEKTLEGGES LESING I DEN NYE NATURFAGPLANEN?}

I følge skolereformen Kunnskapsløftet skal som nevnt lesing og fire andre grunnleggende ferdighetene, vektlegges i alle fag (Utdannings- og forskningsdepartementet, 2004). Ved å se etter den relative vektlegging av lesing i forhold til andre kompetanser vil vi kunne få et inntrykk av hvilken posisjon lesing har fått i den nye naturfagplanen. I Kunnskapsløftet skal alle læringsmål være formulerte som demonstrerbare kompetanser. Fokuset på demonstrerbare kompetanser har flere begrunnelser. For det første skal det tydeliggjøre at opplæringen skal resultere i kunnskaper og ferdigheter som kan anvendes i ulike situasjoner utenfor en skolekontekst. For det andre skal kompetansene være demonstrerbare, slik at det er mulig å teste i hvilke grad den enkelte elev har nådd kompetansemålene. Gjennomlesing av læreplanen i naturfag viser at kompetanseformuleringene ikke inneholder noen egne mål for lesekompetanse. Derimot inneholder alle kompetanseformuleringene verb som kan kalles situasjonsbeskrivende: de beskriver synlige situasjoner eller aktiviteter. Disse verbene forteller hvordan kompetanser skal demonstreres ved at de forteller om eleven skal forklare (f.eks. et begrep), skrive (f.eks. rapporter), drøfte (f.eks. et miljøproblem) eller presentere (f.eks. et prosjekt). (I tillegg vil mange av verbene samtidig signalisere kognitivt nivå på kompetansemålene, sett i lys av f.eks. Bloom, Englehart, Furst, Hill og Krathwohl sine (1956) kunnskapsstiger. Dette ved at verbene vil signalisere om elevene skal reprodusere, anvende eller drøfte det aktuelle kunnskapsstoff.)

Men hvordan skal så elevenes grunnleggende ferdigheter demonstreres i testsituasjoner? Ser vi nærmere på verbene i kompetanseformuleringene i naturfagplanen (Kunnskapsdepartementet, 2006) så ser vi at de typisk også innebærer demonstrering av en grunnleggende ferdighet nettopp ved at de sier noe om hvordan en kompetanse skal demonstreres: Skal eleven vise sin kunnskap gjennom å skrive, eller gjennom å regne, osv. Det vil derfor være mulig å studere kompetansemålene for å se hvilke grunnleggende ferdigheter elevene må demonstrere når deres sluttkompetanser blir testet. I tabell 1 - 4 vises resultatet av en identifisering og opptelling av verb i kompetanseformuleringene i læreplanen for naturfag. I tillegg til antall ganger verbet er brukt eksplisitt har jeg i parentes notert antall ganger samme verb er brukt implisitt. Implisitt betyr her at et verb er brukt i en oppramsing eller i sammenbindinger med ordene "og" eller "samt". Opptellingsstrategien kan beskrives med et eksempel. På 7. trinn, under "Fenomener og stoffer", står følgende kompetansemål:

Mål for opplcringen er at eleven skal kunne beskrive sentrale egenskaper ved gasser, vaesker, faste stoffer og faseoverganger ved hjelp av partikkelmodellen

Det sentrale verbet her er "beskrive". Det er nevnt en gang eksplisitt, men står foran en oppramsing som i tillegg til "gasser" nevner tre andre faglige tema som skal kunne beskrives. Opptellingen her vil resultere i frekvensangivelsen "beskrive $1(+3)$ ", dvs. en gang eksplisitt og tre ganger implisitt. For å forenkle lesingen er tallet 1 ikke notert når et verb bare er brukt eksplisitt en gang. Noen verb, som for eksempel gjengi, beskrive og forklare, åpner både for muntlig og skriftlig demonstrasjon av kompetanser, Slike verb er i tabellene gitt en egen kategori.

Jeg har ikke tatt med regning og digitale ferdigheter i tabellene. Disse ferdighetene er ikke blant de fire klassiske språklige ferdighetene lese, skrive tale og lytte. Det er også relativt få verb som signaliserer regning og digitale ferdigheter. Angående regning er situasjonen den at det på 10. trinn 
står at elevene skal kunne "gjøre forsøk og enkle beregninger med arbeid, energi og effekt ". Denne ene bruken av uttrykket giøre ... beregninger er det eneste i kompetanseformuleringene for 1 . til 11. trinn som signaliserer regning. Digitale ferdigheter kan sies å være noe hyppigere signalisert. Her finner vi verbene finne informasjon, bruke digitale hjelpemidler (ved praktisk arbeid), beskrive datasimuleringer, gjennomfore datasimuleringer, presentere (tre ganger) og publisere. Da digitale ferdigheter ofte bare innebærer at et digital verktøy brukes for eksempel til å presentere vil noen av disse verbene samtidig signalisere skriving eller muntlighet.

Tabell 1. Kompetanseverb i loereplanen i naturfag i Kunnskapsløftet for 2. og 4. trinn

\section{Grunnleggende ferdighet Kompetanseverb og frekvenser 2. og 4. trinn}

gjengi (+2), gi eksempel på, fortelle 7 , beskrive 17 (+9), sette navn på

Skriftlig/muntlig $54 \quad(+1)$, stille spørsmål (+1), sortere/systematisere data 3, bruke 2, presentere 2 , argumentere, drøfte, systematisere informasjon, filosofere

$(+1)$, sammenligne

\begin{tabular}{ll}
\hline Muntlig 12 & samtale $8(+4)$ \\
\hline Skriftlig 2 & notere (observasjoner), dokumentere \\
\hline Lesing 2 & samle...informasjon, finne informasjon \\
\hline
\end{tabular}

Tabell 2. Kompetanseverb for 7. trinn

\section{Grunnleggende ferdighet Kompetanseverb og frekvenser}

\begin{tabular}{ll}
\hline Skriftlig/muntlig 48 & $\begin{array}{l}\text { beskrive } 15(+15), \text { presentere, forklare } 9(+3) \text {, diskutere, gjøre greie for } \\
\text { 3, formulere spørsmål }\end{array}$ \\
\hline Muntlig 6 & fortelle $2(+1)$, samtale $2(+1)$ \\
\hline Skriftlig 1 & publisere \\
\hline Lesing 2 & trekke $\ldots$ ut, samle \\
\hline
\end{tabular}

Tabell 3. Kompetanseverb for 10. trinn

\section{Grunnleggende ferdighet Kompetanseverb og frekvenser 10. trinn}

\begin{tabular}{ll}
\hline Skriftlig/muntlig 74 & $\begin{array}{l}\text { gi eksempler 4, gi en oversikt over, beskrive 9 }(+7), \text { presentere } \\
\text { hovedtrekk, forklare } 13(+11), \text { gjøre greie/rede for } 7(+5), \text { foreslå tiltak, } \\
\text { drøfte } 3(+5), \text { identifisere, evaluere, utvikle, teste, vurdere } 2(+1)\end{array}$ \\
\hline Muntlig 2 & samtale 2 \\
\hline Skriftlig 3 & skrive logg $(+1)$, presentere rapporter \\
\hline Lesing & \\
\hline
\end{tabular}


Tabell 4. Kompetanseverb for 11. trinn

\section{Grunnleggende ferdighet Kompetanseverb og frekvenser 11. trinn}

Skriftlig/muntlig 73

gi eksempler $2(+1)$, beskrive $6(+5)$, forklare $12(+9)$, gjøre rede for 10

$(+4)$, drøfte $2(+5)$, diskutere $(+1)$, argumentere $(+1)$, vurdere $6(+4)$,

analysere, gi en oversikt over, velge ut

\begin{tabular}{ll}
\hline Muntlig & (Se Skriftlig/muntlig) \\
\hline Skriftlig & (Se Skriftlig/muntlig) \\
\hline Lesing & - \\
\hline
\end{tabular}

Tabellene 1 til 4 kan få en til å undres: hvor er det blitt av lesing? Læreplanen bruker verb som innebærer lesing bare fire ganger, og ingen ganger på 10. og 11. trinn!

Den relative vekten på lesing i forhold til andre kognitive ferdigheter blir enda klarere hvis vi teller opp alle verb i naturfagplanen. Ved å kategorisere verbene etter ulike ferdigheter som signaliseres i stedet for bare å telle opp antall verb totalt får vi et tydeligere kvalitativt bilde av det nye naturfagets profil. Gjennomlesing av naturfagplanen viser her at naturfagplanen inneholder en rekke verb som ikke signaliserer noen av de fem grunnleggende ferdighetene nevnt spesielt i læreplanverket, men derimot uttrykker aktiviteter knyttet til praktisk naturfaglig arbeidsmåte. Eksempler her er å delta (i naturen), demonstrere, gjennomføre forsøk, planlegge, bruke utstyr, observere, innhente data, samt lage, bygge og teste. Disse verbene avkrever ikke demonstrasjon av de fem grunnleggende ferdighetene. Derimot signaliserer de kompetanser knyttet til vitenskapsfagets arbeids- og tenkemåter som en slags sjette grunnleggende ferdighet i naturfag. Når denne kategorien legges til de frem grunnleggende ferdighetene får vi et sett på fem kategorier verb som til sammen rommer alle verb i planen.

I tabell 5 er antall verb innen de ulike kategoriene summert opp for 1. til 11. trinn. Tabellen viser at skriftlighet, muntlig og naturfaglig arbeidsmåte er signalisert med 340 verb. Lesing er signalisert med 4 verb, alle på 1. - 7. trinn. Liknende skjebne er blitt regning og digitalitet til del. Lytteferdighet er ikke tatt med i læreplanreformen i det hele tatt. Signalet fra læreplanen synes tydelig: Gjennom naturfaget skal elevene bli dyktige til å presentere naturfaglig kunnskap skriftlig og muntlig, samt praktisere naturfaglige arbeidsmåter. De skal altså bli kompetente til å formidle naturfaglig kunnskap og gjennomføre undersøkelser av naturen. Det som ikke vektlegges er kompetanse i å tilegne seg kunnskap gjennom å lese og lytte. Dette på tross av de senere i livet må sette seg inn i stadig nye kunnskapsområder hvis de skal delta som demokratiske borgere og bevisste forbrukere. Min lesing av danske, finske og svenske læreplaner i naturfagene i grunnopplæringen tyder på at denne vektleggingen ikke er unik for den norske naturfagplanen.

I tillegg til kompetansemål inneholder naturfagplanen en beskrivelse av "Grunnleggende ferdigheter i faget". Om lesing som grunnleggende ferdighet i naturfag står det følgende:

A kunne lese i naturfag dreier seg om å samle informasjon, tolke og reflektere over innholdet i naturfaglige tekster, brosjyrer, aviser, bøker og på Internett. Lesing i naturfag innebcerer også lesing av bruksanvisninger, oppskrifter, tabeller, ulike diagrammer og symboler.

Her er det tydelig at lesing i naturfag innbefatter lesing av ulike typer tekster med naturfaglig innhold. Det som likevel blir mindre klart, er om dette er bindende kompetansemål eller bare en beskrivelse av hvilke typer tekster, med tilhørende tekstelementer, som har naturfaglig innehold. I innledningen til beskrivelsen står det at "Grunnleggende ferdigheter er integrert i kompetansemålene der de bidrar til utvikling av og er en del av fagkompetansen". Men nå så vi at lesing bare i liten grad er integrert i kompetansemålene. Det kan tolkes som at naturfaglærere bare skal arbeide 
Tabell 5. Oppsummering av verb $i$ den norske naturfagplanen

\section{Grunnleggende ferdighet Antall verb (eksplisitte pluss implisitte)}

\begin{tabular}{ll}
\hline Skriftlig/muntlig & 249 \\
\hline Muntlig & 20 \\
\hline Skriftlig & 6 \\
\hline Lesing & 4 \\
\hline Regning & 3 \\
\hline Digitale verktøy & 8 \\
\hline Naturfaglig arbeidsmåte & 91 \\
\hline
\end{tabular}

med lesing av slike tekster "der de bidrar til utvikling av og er en del av fagkompetansen". Mange lærere opplever naturfaget som fullpakket med fagstoff som elevene skal lære. Når lesing ikke inngår i kompetanseformuleringene som ligger til grunn for testing og karaktersetting vil det her være en fare for at leseopplæring vil bli nedprioritert. Min konklusjon er derfor at lesing av naturfaglige tekster ikke er gitt en oppmerksomhet i naturfagplanen som står i forhold til viktigheten av lesing gitt de overordnede mål for fag og skole.

I sitatet ovenfor er "naturfaglige tekster" skilt ut som egen kategori. Det er da rimelig å tolke disse som noe i retning av den type tekster som naturvitere bruker, selv om ikke spesifikke naturfaglige sjangre er oppgitt. Selv om ikke spesielle muntlige og skriftlige sjangre er nevnt i selve kompetanseformuleringene, vil disse i praksis indikere sjangre elevene skal bruke når de i testsituasjoner skal demonstrere sine kompetanser. Gitt verbene i kompetanseformuleringene er det tydelig at beskriving og forklaring er sjangre elevene skal kjenne. Verb som argumentere, drøfte og gjøre rede for inngår også, og kan tolkes som at elevene skal kjenne til bruken av utredning eller andre argumenterende sjangre. I hovedområdet "Forskerspiren" for 10. trinn står det at elevene skal kunne "skrive logg ved forsøk og feltarbeid og presentere rapporter" samt "forklare hvorfor argumentering, uenighet og publisering er viktig i naturvitenskapen". Her er det tydelig at elevene skal kunne kjenne til naturfaglig eksperimentrapport. Men det ser ikke ut til at læreplanen krever at elevene skal kunne lese i disse ulike sjangrene, selv om de skal kunne skrive i dem!

\section{MANGEL PÅ TRADISJON FOR LESEOPPLAERING I NATURFAG}

Når lesing og leseopplæring ser ut til å være lite vektlagt i naturfagplanen kan det tenkes å være et uttrykk for en tradisjon i norsk skole. I prosjektet PISA+ om lærings- og undervisningsstrategier i norsk skole (Klette, Ødegaard, Anmarkrud, Arnesen, Bergem \& Roe, 2008) ble 136 undervisningstimer i naturfag, norsk og matematikk i seks ulike niendeklasser analyserte. De fant at lærerne i studien manglet kunnskap om utvikling av elevers leseforståelse og lesestrategier og at de fleste knyttet lesestrategier til avkoding og lesetekniske ferdigheter. Lundberg m.fl. (1993), referert i PISA 2000 (Lie m.fl., 2001, s.34), viser til klasseromsobservasjoner i andre land der det konstateres at leseundervisning knapt forekommer ut over begynneropplæringen. Lundberg fremholder også at undersøkelser tyder på at lærere hovedsakelig oppfatter leseopplæring som teknisk ordavkoding, og at når denne er tilegnet, kommer resten av seg selv etter hvert som elevene leser mer og får mer trening. Norris og Phillips (2003) hevder at en slik forståelse også kommer til uttrykk i mange forskningsartikler i naturfagdidaktikk. I sine undersøkelser i USA fant Pressley (2006) at 
den leseundervisningen som foregikk var av svært ulik kvalitet og at det de fleste steder ble det lagt liten vekt på lesekompetanse og leseforståelse. Helgevold og Engen (2006) hevder at lærere typisk er mer opptatt av å evaluere elevenes læring i etterkant av leseaktiviteter enn å undervise i lesing med forståelse. Dette kommer til uttrykk gjennom bruken av skriftlige og muntlige kontrollspørsmål. Fokuset på kontrollspørsmål kjenner vi igjen i den typiske dialogen i naturfagundervisningen der lærer stiller spørsmål, elevene responderer og lærer evaluerer svar (Mortimer \& Scott, 2003). Helgevold og Engen (2006) peker på at en mulig konsekvens av en slik tradisjon kan være at elevene erfarer at lesing mer handler om å svare på andres spørsmål enn å kunne stille sine egen, samtidig som det siste er et viktig kjennetegn på dyktige lesere av fagtekster.

I det forrige norske læreplanverket, L97 (Kirke-, utdannings- og forskningsdepartement, 1996), manglet selv norskfaget konkrete mål for arbeid med lesestrategier og tekstforståelse utover kunnskap om sjangertrekk og teksters oppbygging og virkemidler. I den norske hovedrapporten fra PISA 2000 (Lie m.fl., 2001), hvor lesing var det vektlagte faget, hevdes det at "Dersom L97 gjenspeiler hva slags leseopplæring som foregår i norske klasserom på ungdomstrinnet, er det grunn til å spørre om dette er bra nok" (s.35).

Ser vi på resultater for læringsstrategitestene i PISA studiene i 2000 (Lie m.fl., 2001) og 2003 (Kjærnsli, Lie, Olsen, Roe \& Turmo, 2004) finner vi at norske elever gjennomgående rapporterte mindre bruk av slike, inkludert kontrollstrategier, enn OECD-gjennomsnittet. Disse resultatene kan tyde på at norske lærere i mindre grad vektlegger opplæring i læringsstrategier, inkludert lesestrategier, enn lærere i andre land. I PISA studiene brukes autentiske (oversatte) naturfaglige tekster som kontekst i mange av oppgavene for å gjøre dem virkelighetsnære. Svake leseferdigheter i naturfag kan være en av årsakene til norske elevers plassering i underkant av OECDgjennomsnittet på naturfagskåre.

Nå kan praksis i klasserommene være annerledes enn det en kan lese seg til i læreplaner. Gitt det vi har av indikasjoner er det likevel grunn til å tro at lesing er lite vektlagt i naturfaget i norsk skole. Med den tvetydige vektleggingen som lesing har fått i den nye naturfagplanen er det ikke gitt at denne tradisjonen vil bli endret fremover.

\section{SLUTTKOMMENTARER}

I denne artikkelen har jeg pekt på at det å kunne lese naturfaglige tekster er viktig som allmenndannelse og som grunnlag for livslang læring og demokratisk deltagelse. Lesing med forståelse er et nødvendig grunnlag for å kunne reflektere over det vi leser og stille oss kritiske til innholdet. Samtidig har vi mange indikasjoner på at mange elever strever med å lese fagtekster med forståelse, inkludert naturfaglige tekster. Gjennomgangen av den nye norske læreplanen i naturfag viste at verb som signaliserer krav til lesekompetanse nærmest er fraværende i de formulerte kompetansemål. Dette på tross av en eksplisitt målsetting i læreplanreformen om å vektlegge lesing og andre grunnleggende kompetanser. Fra ulike forskningsprosjekt så vi også klare indikasjoner på at leseopplæring internasjonalt sett er lite vektlagt i undervisning i naturfag.

Hvis det ikke er tradisjon i naturfaget for opplæring i lesing med forståelse så vil det være viktig å ha en læreplan som kan være med å fremme en endring mot økt vekt på lesing. Min gjennomgang tyder på at den nye læreplanen ikke representerer en slik hjelp. Konklusjonen må derfor bli at vi i Norge, og kanskje også i mange andre land, har en utfordring i naturfag knyttet til leseopplæring.

Det er vanskelig å si noe sikkert om årsakene til det som ser ut til å være en manglende oppmerksomhet på viktigheten av å kunne lese naturfaglige tekster med forståelse. En mulig årsak kan være fokuset på kognitiv forståelse som hovedutfordringen i naturfagene. Tidligere ble lærerens gode forklaringer og læring gjennom lytting høyt ansett. Med konstruktivismens inntog ble fokuset flyttet fra lærerens forklaring til elevens forståelse, og nye arbeidsformer ble utviklet og tatt i bruk. Ny- 
ere diskusjoner om naturfaglig allmenndannelse fokuserer på elevenes mulighet for å kunne delta i ulike sammenhenger, en deltagelse som ofte vil fordre lesing av tekster med naturfaglig innhold. Selv om kognitiv forståelse alltid vil være avgjørende viktig i naturfag, så kan vi her spørre om det ikke nettopp er økt evne til deltagelse som bør være begrunnelsen for å utvikle elevenes begrepsforståelse. Fokuset på forståelse må derfor suppleres med vektlegging av lesing for at naturfaget skal forberede til demokratisk deltagelse.

Hvis leseopplæring bør bli en integrert del av naturfagundervisingen blir det viktig å vurdere hvordan en slik endring av tradisjonen kan fremmes. I del 2 av denne dobbelt-artikkelen (Kolstø, 2009) vil jeg derfor vise til forskning som viser at det er mulig å lære elever å lese fagtekster med forståelse på lik linje med læring av andre kunnskaper og ferdigheter. På bakgrunn av innsikter fra leseforskning og kunnskaper om naturvitenskapenes egenart vil jeg der legge frem et forslag til elementer for leseopplæring i naturfag som fokuserer på ulike naturfaglige teksttyper og konkrete mål for lesestrategier.

\section{REFERANSER}

Anderson, J. R., Simon, H. A. \& Reder, L. M. (1996). Situated learning and education. Educational Researcher, 25(4), 5-11.

Bazerman, C. (1998). Shaping written knowledge. The genre and activity of the experimental article in science. Madison, Wisconsin: The University of Wisconsin Press.

Bloom, B., Englehart, M., Furst, E., Hill, W. \& Krathwohl, D. (1956). Taxonomy of educational objectives: The classification of educational goals. Handbook I: Cognitive domain. New York, Toronto: Longmans, Green.

Brandt, H., Fonstad,T., Hushovd, O. T. \& Tellefsen, C. W. (2006). Naturfag 5. Grunnbok. Oslo, Aschehoug.

Brill, G., Falk, H. \& Yarden, A. (2004). The learning processes of two high-school biology students when reading primary literature. International Journal of Science Education, 26(4), 497-512.

Bryant, D. P., Ugel, N., Thomson, S \& Hamff, A. (1999). Instructional strategies for content-area reading instruction. Intervention in School and Clinic, 34(5), 293-302.

Dole, J. A., Duffy, G. G., Roehler, L. R. \& Pearson, P. D. (1991). Moving from the old to the new: Research on reading comprehension instruction. Review of Educational Research, 61(2), 239-264.

Edling, A. (2006). Abstraction and authority in textbooks. The textual paths towards specialized language. Doctoral thesis. Uppsala: Uppsala University. Hentet 25.10.08 fra http://publications.uu.se/theses.

Knain, E. (2002). Naturfagboka i praksis. Om tolv naturfagelever og deres laerebok. Tønsberg: Høgskolen i Vestfold, 2002 Rapport 10/2002. Hentet 10.11 .08 fra http://www-bib.hive.no/ tekster/hveskrift/rapport/2002-10/rapport10-2002.pdf

Kolstø, S. D. (2006). Et allmenndannende naturfag. Fagets betydning for demokratisk deltagelse. NorDiNa, (5), 82-99.

Kolstø, S. D. (2009). Vektlegging av lesing i naturfaget. Del 2: Hvordan fremme elevens kompetanse i å lese naturfaglige tekster? NorDiNa, dette nr.

Gregg, M. \& Sekers, D. C. (2006). Supporting children's reading of expository text in the geography classroom. The Reading Teacher, 60(2), 102-110.

Halliday, M. A. K. \& Martin, J. R. (1993) (Red), Writing science: Literacy and discursive power (s. 166-220). Pittsburgh, PA: University of Pittsburgh Press.

Helgevold, L. \& Engen, L. (2006). Fagbok i bruk: Å lese en fagtekst. I L. Helgevold \& L. Engen (Red.). Fagbok i bruk (s. 6-15). Stavanger: Nasjonalt senter for leseopplæring og leseforskning. 
Keys, C. W., Hand, B., Prain, V. \& Collins, S. (1999). Using the science writing heuristic as a tool for learning from laboratory investigations in secondary science. Journal of Research in Science Teaching, 36(10), 1065-1084.

Kjærnsli, M., Lie, S., Olsen, R. V., Roe, A. \& Turmo, A. (2004). Rett spor eller ville veier. Norske elevers prestasjoner i matematikk, naturfag og lesing i PISA 2003. Oslo: Universitetsforlaget.

Kjærnsli, M., Lie, S., Olsen, R. V. \& Roe, A. (2007). Tid for tunge løft. Norske elevers kompetanse $i$ naturfag, lesing og matematikk i PISA 2006. Oslo: Universitetsforlaget.

Klette, K., Lie, S., Ødegaard, M., Anmarkrud, Ø., Arnesen, N., Bergem, O. K. \& Roe, A. (2008). Rapport om forskningsprosjektet PISA+. Norges forskningsråd. Hentet 21.04.08 fra www. forskningsradet.no/utdanning

Kunnskapsdepartementet (2006). Lcereplan i naturfag. Hentet 21.04 .08 fra http://www.udir.no under Kunnskapsløftet - fag og læreplaner. Finnes også i dokumentet Læreplanverket for Kunnskapsløftet (Midlertidig utg. juni 2006). Oslo: Utdanningsdirektoratet.

Kirke-, utdannings- og forskningsdepartement (1996). Løereplanverket for den 10-årige grunnskolen (L97). Oslo, Kirke-, utdannings- og forskningsdepartement. Hentet 21.04.08 fra http:// www.udir.no

Latour, B. (1987). Science in action: How to follow scientists and engineers through society. Milton Keynes: Open University Press.

Layton, D. (1991). Science education and praxis: the relationship of school science to practical action. Studies in Science Education, 19, 43-79.

Lemke, J. (1998). Multyplying meaning. Visual and verbal semiotics in scientific texts. I J. R. Martin \& R. Veel (Red.), Reading science. Critical and functional perspectives on discourses of science. London: Routledge.

Lewis, J., \& Leach, J. (2006). Discussion of socio-scientific issues: The role of science knowledge. International Journal of Science Education, 28(11), 1267-1287.

Lie, S., Kjærnsli, M., Roe A. \& Turmo A. (2001). Godt rustet for framtida? Norske 15-åringers kompetanse i lesing og realfag i et internasjonalt perspektiv. Acta Didactica, 4

Løvland, A. (2006). Sammensatte fagtekster - en multimodal utfordring? I E. Maagerø \& E. S. Tønnesen (Red.). A lese $i$ alle fag (s. 109-125). Oslo: Universitetsforlaget.

Martin, J. R. (1993a). Life as a noun: Arresting the universe in science and humanities. I M. A. K. Halliday \& J. R. Martin (Red.), Writing science: Literacy and discursive power (s. 166-220). Pittsburgh, PA: University of Pittsburgh Press.

Martin, J. R. (1993b). Literacy in science: Learning to handle text as technology. I M. A. K. Halliday \& J. R. Martin (Red.), Writing science: Literacy and discursive power (s. 166-220). Pittsburgh, PA: University of Pittsburgh Press.

Mortensen-Buan, A.-B. (2006). Lesestrategier og metoder. IE. Maagerø \& E. S. Tønnesen (Red.). A lese $i$ alle fag (s.165-189). Oslo: Universitetsforlaget.

Mortimer, F. \& Scott, P. H. (2003). Meaning making in secondary science classrooms. Maidenhead: Open University Press.

Maagerø, E. (2006). Om å lese på setningsnivået. I E. Maagerø \& E. S. Tønnesen (Red.). Å lese $i$ alle fag (s. 65-87). Oslo: Universitetsforlaget.

Maagerø, E. \& E. S. Tønnesen (2006a). Å lese i alle fag. I E. Maagerø \& E. S. Tønnesen (Red.). $A$ lese $i$ alle fag (s. 13-30). Oslo: Universitetsforlaget.

Norris, S. P. \& Philips, L. M. (1994). Interpreting pragmatic meaning when reading popular reports of science. Journal of Research in Science Teaching, 31(9), 947-967.

Norris, S. P. \& Phillips, L. M. (2003). How literacy in its fundamental sense is central to scientific literacy. Science Education, 87, 224-240.

Phillips, L. M. \& Norris, S. P. (1999). Interpreting popular reports of science: What happens when the reader's world meets the world on paper? International Journal of Science Education, 21(3), 317-327.

Osborne J., Collins, S., Ratcliffe, M., Millar, R. \& Duschl, R. A. (2003). What "ideas-about-science" should be taught in school science? A Delphi study of the expert community. Journal of Research in Science Teaching, 40(7), 692-720 
Pressley, M. (2006). Reading instruction that works. The case for balanced teaching. London: The Guilford Press.

Purcell-Gates, V., Duke, N. K. \& Martineau, J. A. (2007). Learning to read and write genre-specific text: Roles of authentic experience and explicit teaching. Reading Research Quarterl,y 42(1), 8-45.

Quiocho, A. (1997). The quest to comprehend expository text: Applied classroom research. Journal of Adolescent \& Adult Literacy, 40(6), 450-456.

Ratcliffe, M. (1999). Evaluation of abilities in interpreting media reports of scientific research. International Journal of Science Education, 21(10), 1085-1099.

Sjøberg, S. (2007). Internasjonale undersøkelser: Grunnlaget for norsk utdanningspolitikk? I H. Hølleland (Red.), På vei mot Kunnskapsløftet. Begrunnelser, løsninger og utfordringer (s. 326). Oslo: Cappelen Damm.

Utdannings- og forskningsdepartementet (2004). Kultur for loering. Stortingsmelding $n r$. 30. Oslo: Utdannings- og forskningsdepartement.

Utdannings- og forskningsdepartementet (2003). I første rekke. Forsterket kvalitet i en grunnopploering for alle (Kvalitetsutvalget). NOU 2003:16. Oslo: Statens forvaltningstjeneste.

Veel, R. (1997) Learning how to mean - scientifically speaking: apprenticeship into scientific discourse in the secondary school. I F. Christie \& J.R. Martin (Red.): Genre and institutions: Social processes in the workplace and school. London: Continuum.

Wellington, J., \& Osborne, J. (2001). Language and literacy in science education. Buckingham: Open University Press. 